\title{
PERSEPSI MASYARAKAT TENTANG GADAI EMAS DI PEGADAIAN SYARIAH CABANG KARAWANG
}

\author{
Nana Diana \\ Widya Febryari Anita \\ Program Studi Akuntansi, Fakultas Ekonomi dan Bisnis \\ Universitas Singaperbangsa Karawang \\ J1. Ronggowaluyo Telukjambe Timur Karawang \\ Email:nanadiana.ekonomi@gmail.com \\ widya.febryari@gmail.com
}

\begin{abstract}
Abstrak
Persepsi diawali dengan penglihatan yaitu sesuatu keadaan yang ditangkap oleh mata ketika peserta didik diberikan rangsangan. Persepsi memiliki kaitan erat antara panca indera dengan otak manusia. Menurut Karwono dan Mularsih (2010: 24) menyatakan bahwa "Persepsi adalah interpretasi tentang situasi yang hidup." Ar-rahn (gadai) adalah harta yang dijadikan jaminan utang (pinjaman) agar bisa dibayar dengan harganya oleh pihak yang wajib membayarnya, jika dia gagal(berhalangan) melunasiny.

Metode analisis yang digunakan dalam penelitian ini adalah dengan metode deskriptif, dimana data yang diperoleh dianalisis sehingga diperoleh berbagai gambaran yang menunjukkan persepsi masyarakat tentang gadai emas di Pegadaian Syariah. Disamping itu dilakukan pula dengan bentuk analisis lain seperti : grafik tabulasi silang (cross tab), tabel, frekuensi dan gambar (grafik).Dengan jumlah populasi nasabah yang aktif 1 tahun terakhir yaitu sebanyak 120 dan diambil sampel sebanyak 80 orang.

Dari alasan nasabah memilih Pegadaian Syariah sebagai suatu solusi dalam menggadaikan emas dapat dilihat bahwa alasan nasabah memilih Perum Pegadaian Syariah sebagai solusi dalam menggadaiakan emas mempunyai alasan yang beragam. Hal itu didasarkan pada jumlah responden sebanyak 47 orang atau sebesar $58,75 \%$ dari total responden menyatakan bahwa alasannya menggadaikan emas di Pegadaian Syariah karena proses menggadaikan emas dengan syarat yang mudah, cepat dan aman. Sebanyak 29 orang atau sebesar 36,25\% dari total responden menyatakan segala biaya yang ada persentasenya $5 \%$ kecil, sehingga tidak memberatkan peminjam. Sebanyak 3 orang atau sebesar 3,75\% dari total responden menyatakan tidak ada pilihan lain.Dengan demikian dapat disimpulkan bahwa nasabah menggadaikan emasnya di Pegadaian Syariah dengan alasan karena proses menggadaikan emas dengan syarat yang mudah, cepat dan aman.
\end{abstract}


Kata Kunci : Persepsi, Pemahaman dan Gadai emas

\section{Pendahuluan}

Berawal dari Bank Van Lening pada masa VOC, yang mempunyai tugas untuk memberikan pinjaman uang kepada masyarakat dengan jaminan gadai, kemudian muncul lah bentuk usaha pegadaian di Indonesia. Sejak itu, bentuk usaha pegadaian telah mengalami beberapa kali perubahan sejalan dengan perubahan peraturan-peraturan yang mengaturnya. Pegadaian di Indonesia awalnya dilaksanakan oleh pihak swasta, kemudian melalui Staatsblad Tahun 1901 NO.131 tanggal 12 Maret 1901, Gubernur Jenderal Hindia Belanda mendirikan Rumah Gadai Pemerintah (Hindia Belanda) di Sukabumi, Jawa Barat. Bersamaan dengan dikeluarkannya peraturan tersebut, maka pelaksanaan gadai dilakukan oleh Pemerintah Hindia Belanda sebagai mana diatur dalam Staatsblad Tahun 1901 No. 131, tersebut yang berbunyi: "Kedua: Sejak saat itu di bagian Sukabumi kepada siapapun tiak akan diperkenankan untuk memberi gadai atau dalam bentuk jual beli dengan hak membeli kembali, meminjamkan uang, tidak melebihi seratus Golden, dengan hukuman, tergantung pada kebangsaan para pelanggar yang diancam dalam pasal 337 KUHP bagi orang-orang Eropa dan pasal 339 KUHP bagi orang-orang BumiPutera". Kemudian, denganStaatsblad 1930 No. 266, Rumah Gadai tersebut mendapatkan status dari Dinas Pegadaian sebagai Perusahaan Negara dalam arti Undang-Undang Perusahaan Hindia Belanda ( Lembaga Hindia Belanda 1927 No. 419) (Siamat, 2005: 743).

Sebagian umat islam di Indonesia yang mampu mensyukuri nikmat Allah itu mulai memanfaatkan peluang tersebut dengan mendukung berdirinya bank syariah, asuransi syariah, dan reksadana syariah dalam bentuk menjadi pemegang saham, menjadi penabung dan nasabah, menjadi pemegang polis, menjadi investor, dan sebagainya.

Investasi syariah merupakan salah satu ajaran dalam konsep Islam yang memenuhi proses tadrij (memiliki gradasi) dan trichonomy pengetahuan yang bernuansa spiritual karena menggunakan norma agama dan merupakan hakikat dari ilmu dan amal. Hal tersebut dapat dibuktikan bahwa konsep investasi selain sebagai pengetahuan juga bernuansa spiritual karena menggunakan norma Islam, sekaligus merupakan hakekat dari sebuah ilmu dan amal, oleh karenanya investasi sangat dianjurkan bagi setiap muslim. Hal tersebut dijelaskan dalam al-Qur'an surat alHasyr ayat 18 sebagai berikut : ( Nurul Huda dan Mohammad Heykal, 2010:186)

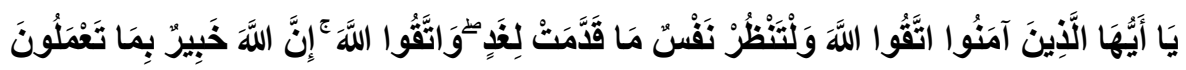

\footnotetext{
${ }^{1}$ Nurul Huda dan Mohammad Heykal, LembagaKeuangan Islam: TinjauanTeoritisdanPraktis (Jakarta: Kencana, 2010), 186
} 
Hai orang-orang yang beriman, bertakwalah kepada Allah dan hendaklah setiap diri memperhatikan apa yang telah diperbuatnya untuk hari esok (akhirat); dan bertakwalah kepada Allah, sesungguhnya Allah Maha Mengetahui apa yang kamu kerjakan.

Dari pengalaman mendirikan bank syariah dan asuransi syariah, serta reksadana syariah, diperlukan pengkajian yang mendalam terlebih dahulu, sehingga dengan demikian untuk berdirinya pegadaian syariahpun diperlukan pengkajian terhadap berbagai aspeknya secara luas dan mendalam.

Informasi segmen Perusahaan disajikan berdasarkan geografis dibagi dalam 5 (lima) wilayah yang terdiri dari:

Tabel 1.1

\section{Kantor Cabang dan Unit Pelayanan Cabang Syariah}

\begin{tabular}{|c|c|c|c|}
\hline Kantor Wilayah & Tempat/ Wilayah Pembinaan & $\begin{array}{l}\text { Jumlah } \\
\text { Cabang }\end{array}$ & $\begin{array}{l}\text { Jumlah } \\
\text { Unit }\end{array}$ \\
\hline $\begin{array}{l}\text { Kantor Wilayah } \\
\text { Medan }\end{array}$ & $\begin{array}{l}\text { Sumatera Utara dan Nanggroe Aceh } \\
\text { Darussalam }\end{array}$ & 17 & 66 \\
\hline $\begin{array}{l}\text { Kantor Wilayah } \\
\text { Pekanbaru }\end{array}$ & $\begin{array}{l}\text { Sumatera Barat, Riau, dan } \\
\text { Kepulauan Riau }\end{array}$ & 5 & 35 \\
\hline $\begin{array}{l}\text { Kantor Wilayah } \\
\text { Palembang }\end{array}$ & $\begin{array}{l}\text { Jambi, Bengkulu, Sumatera Selatan, } \\
\text { Lampung, dan Bangka Belitung }\end{array}$ & 5 & 35 \\
\hline $\begin{array}{l}\text { Kantor Wilayah } \\
\text { Balikpapan }\end{array}$ & $\begin{array}{l}\text { Kalimantan Barat, Kalimantan } \\
\text { Timur, } \\
\text { Kalimantan Selatan, dan Kalimantan } \\
\text { Tengah }\end{array}$ & 11 & 28 \\
\hline $\begin{array}{l}\text { Kantor Wilayah } \\
\text { Manado }\end{array}$ & $\begin{array}{l}\text { Sulawesi Utara, Sulawesi Tengah, } \\
\text { Gorontalo, Maluku Utara, dan } \\
\text { Papua }\end{array}$ & 11 & 30 \\
\hline $\begin{array}{l}\text { Kantor Wilayah } \\
\text { Makassar }\end{array}$ & $\begin{array}{l}\text { Sulawesi Selatan, Sulawesi } \\
\text { Tenggara, } \\
\text { dan Maluku }\end{array}$ & 12 & 37 \\
\hline $\begin{array}{l}\text { Kantor Wilayah } \\
\text { Denpasar }\end{array}$ & $\begin{array}{l}\text { Bali, Nusa Tenggara Barat, } \\
\text { dan Nusa Tenggara Timur }\end{array}$ & 6 & 33 \\
\hline
\end{tabular}




\begin{tabular}{|l|l|l|l|}
\hline $\begin{array}{l}\text { Kantor Wilayah } \\
\text { Jakarta I }\end{array}$ & $\begin{array}{l}\text { Jakarta Pusat, Jakarta Timur, } \\
\text { Depok, } \\
\text { Bekasi, dan Bogor }\end{array}$ & 74 \\
\hline $\begin{array}{l}\text { Kantor Wilayah } \\
\text { Jakarta II }\end{array}$ & $\begin{array}{l}\text { Jakarta Utara, Jakarta Selatan, } \\
\text { Jakarta } \\
\text { Barat, dan Banten }\end{array}$ & 10 & 45 \\
\hline $\begin{array}{l}\text { Kantor Wilayah } \\
\text { Bandung }\end{array}$ & Jawa Barat & 10 & 55 \\
\hline $\begin{array}{l}\text { Kantor Wilayah } \\
\text { Semarang }\end{array}$ & Jawa Tengah dan Yogyakarta & 9 & 39 \\
\hline $\begin{array}{l}\text { Kantor Wilayah } \\
\text { Surabaya }\end{array}$ & Jawa Timur & 12 & 43 \\
\hline $\begin{array}{l}\text { Jumlah Cabang } \\
\text { Jumlah CPS dan UPS Syariah }\end{array}$ & 115 & 500 \\
\hline
\end{tabular}

Sumber : Annual Report 2014

Kabupaten karawang sendiri terdiri atas 30 Kecamatan yang dibagi lagi atas 197 desa dan 12 Kelurahan. Sumber penghasilan utamanya sedikit bergeser yang awalnya dari pertanian mejadi Kota Industri. Terlihat dari banyaknya kawasankawasan industri, seperti : KIIC, BIC, KIM dan Surya cipta. Karena hal tersebut sedikit banyak mampu mempengaruhi kegiatan ekonomi yang dilakukan oleh masyarakat.Kegiatan ekonomi yang semakin beragam akibat dari kebutuhan masyarakat yang semakin heterogen adanya lembaga keuangan yang berbasis syariah salah satunya adalah Pegadaian syariah menjadi salah satu jawaban dari keberagaman kebutuhan dalam hal keuangan bagi masyarakat sendiri.

Berdasarkan latar belakang dan fenomena yang telah diuraikan tersebut, maka menarik perhatian peneliti untuk mengkaji dan meneliti secara mendalam tentang "Persepsi Masyarakat Tentang Gadai Emas Di Pegadaian Syariah Cabang Karawang".

\section{Landasan Teori}

2.1 Pengertian Persepsi

Setiap manusia yang memiliki panca indera berkemungkinan untuk membentuk persepsi-persepsi masing-masing dalam pikirannya. Baik itu persepsi 
positif maupun persepsi negatif tergantung pada pengalaman yang ditangkap panca inderanya. Persepsi diawali dengan penglihatan yaitu sesuatu keadaan yang ditangkap oleh mata ketika peserta didik diberikan rangsangan. Persepsi memiliki kaitan erat antara panca indera dengan otak manusia. Menurut Karwono dan Mularsih (2010: 24) menyatakan bahwa "Persepsi adalah interpretasi tentang situasi yang hidup."

Sejalan dengan Rakhmat (2011: 50) bahwa "Persepsi adalah pengalaman tentang objek, peristiwa, atau hubungan-hubungan yang diperoleh dengan menyimpulkan informasi dan menafsirkan pesan.” Demikian persepsi menyangkut dengan pengalaman seseorang tentang suatu situasi dan peristiwa dan menafsirkan informasi yang terkandung dari situasi yang dialami. Kemudian senada dengan pendapat diatas, menurut Walgito (2010: 99) menyatakan persepsi merupakan:

Suatu proses yang didahului oleh proses penginderaan, sedangkan penginderaan merupakan suatu proses diterimanya stimulus oleh individu melalui alat indera atau juga disebut proses sensori. Stimulus yang mengenai alat individu tersebut kemudian diorganisasikan, diinterpretasikan, sehingga individu menyadari tentang apa yang diinderanya itu.

Menurut David Krech dan Ricard Crutcfield dalam Jalaludin Rahmat (2007:55) faktor-faktor yang menentukan persepsi dibagi menjadi dua yaitu : faktor fungsional dan faktor struktural.

1. Faktor Fungsional

Faktor fungsional adalah faktor yang berasal dari kebutuhan, pengalaman masa lalu dan hal-hal lain yang termasuk apa yang kita sebut sebagai faktor-faktor personal. Faktor fungsional yang menentukan persepsi adalah obyek-obyek yang memenuhi tujuan individu yang melakukan persepsi. Yang menentukan persepsi bukan bentuk atau jenis stimuli tetapi karakteristik orang yang memberikan respon pada stimuli tersebut.

2. Faktor Struktural

Faktor struktural adalah faktor-faktor yang berasal semata-mata dari sifat stimulus fisik terhadap efek-efek syaraf yang ditimbulkan pada sistem saraf individu. Faktor-faktor struktural yang menentukan persepsi menurut teori Gestalt bila kita ingin memahami suatu peristiwa kita tidak dapat 
meneliti faktor-faktor yang terpisah tetapi memandangnya dalam hubungan keseluruhan.

\subsection{Konsep Gadai dan Teori}

Rahn adalah menahan salah satu harta milik si peminjam sebagai jaminan atas pinjaman yang diterimanya. Barang yang ditahan tersebut memiliki nilai ekonomis. Dengan demikian, pihak yang menahan memperoleh jaminan untuk dapat mengambil kembali seluruh atau sebagian piutangnya. (Antonio, Muhammad Syaafi'i. 2011)

Gadai syariah (Rahn) adalah harta yang tertahan sebagai jaminan utang sehingga bila tidak mampu melunasinya, harta tersebut menjadi bayarannya sesuai dengan nilai utangnya. (Habiburrahman dan Rahmawati, Yulia. 2012)

Ar-rahn (gadai) adalah harta yang dijadikan jaminan utang (pinjaman) agar bisa dibayar dengan harganya oleh pihak yang wajib membayarnya, jika dia gagal(berhalangan) melunasiny. Gadai (Rahn) adalah menahan barang jaminan yang bersifat materi milik si peminjam ( rahin) sebagai jaminan atas pinjaman yang diterimanya, dan barang yang diterima tersebut bernilai ekonomis, sehinga pihak yang menahan (murtahin) memperoleh jaminan untuk mengambil kembali seluruh atau sebagian utangnya dari barang gadai dimaksud, bila pihak yang menggadaikan tidak dapat membayar utang pada waktu yang ditentukan. (Ali, Zainuddin. 2008: 3)

\section{Analisis Hukum Islam Terhadap Praktik Gadai Di PERUM Pegadaian}

\section{Syariah}

Pegadaian Syariah telah mengeluarkan beberapa produk jasa antara lain: gadai syariah, jual beli emas logam mulia (produk mulia) dan arrum. Dari tiga produk tersebut ada praktik produk pegadaian syariah yang hampir sama yaitu arrum dengan gadai syariah. Jasa-jasa tersebut telah didipraktikkan sebagaimana perjanjian yang didiskripsikan di atas yang berlandaskan prinsip-prinsip syariah. Secara umum perjanjian yang di gunakan dalam operasional jasa-jasa tersebut adalah akad rahn, akad ijarah dan akad jual beli murabahah.

\section{1) Gadai Syariah}


Gadai syariah atau rahn telah di perbolehkan oleh al-Qur'an dan as-Sunnah untuk bermuamalah berdasarkan gadai. Dasarnya adalah:

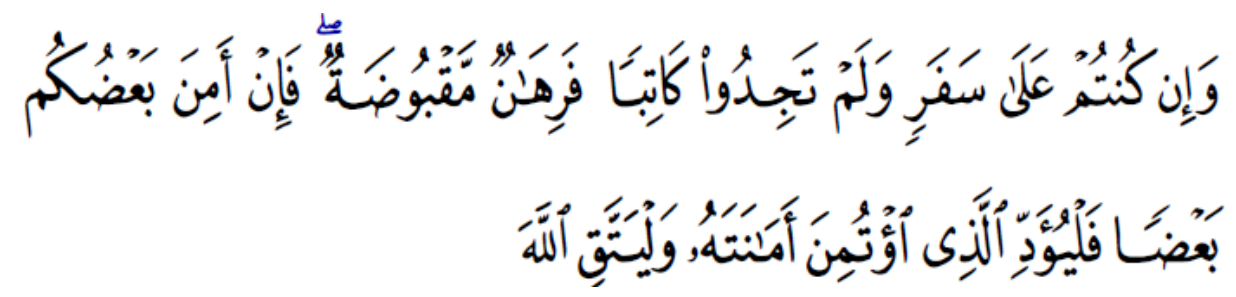

"Dan jika kamu dalam perjalanan (safar) dan kamu tidak dapati penulis, maka hendaklah ada jaminan (borg sebagai barang gadaian) yang kamu pegangi. Maka jika sebagian kamu mempercayai sebagian yang lain, maka hendaklah orang yang dipercayai itu menunaikan amanahnya (hutangnya) dan hendaklah ia takut kepada allah Tuhannya." (Qs. Al-Baqarah, 283)

Sedangkan akad yang telah terjadi di Pegadaian Syariah telah di atur mulai dari nama akad, subyek dan obyek akad, para pihak dalam akad bahkan sampai pada penyelesaian akad. Hal ini bila merujuk pada norma-norma yang ada dalam fiqih muamalah menurut Khalid Samhudi, bahwa akad rahn harus mempunyai empat rukun antara lain (internet september 11,2007) :

(a) Al Rahn atau Al Marhuun (barang yang digadaikan)

(b) Al Marhun bih (hutang)

(c) Shighat

(d) Dua pihak yang bertransaksi yaitu Raahin (orang yang menggadaikan) dan Murtahin (pemberi hutang).

Sedangkan dalam referensi lain menyebutkan bahwa rukun rahn itu terdiri dari (Mahsin Hj. Mansor,1992:68):

(a) Al-rahin adalah orang yang menggadaikan barang untuk mendapatkan pinjaman uang;

(b) Al-murtahin adalah orang penerima gadai karena ia memberikan pinjaman uang;

(c) Al-marhun adalah barang yang dijadikan jaminan hutang;

(d) Sighat adalah ijab dan qabul.

Para pihak yang bertransaksi bisa juga tidak hanya dua pihak tetapi bisa tiga pihak yaitu : pihak raahin, pihak murtahin dan pihak ketiga yang menjamin atas 
hutang-hutang raahin. Hal ini bisa terjadi pada saat barang yang di gadaikan itu milik orang lain, atau barang itu telah di jual kepada pihak ke-tiga.

Pihak ke-tiga tersebut di sebut juga pemberi gadai atau raahin hanya saja tanggung jawabnya hanya terbatas sebesar benda gadai yang ia berikan, sedangkan lebih dari itu tetap menjadi tanggungan debitur raahin sendiri. Pihak ketiga pemberi gadai tidak mempunyai hutang tetapi secara yuridis ia mempunyai tanggungjawab dengan benda gadaiannya.

Bila menganalisis perjanjian yang di buat oleh para pihak, keempat rukun yang di butuhkan oleh perjanjian rahn telah terpenuhi. Bahkan yang di perjanjikan tidak hanya itu saja, ada hal-hal lain yang di perjanjikan berkaitan dengan al-rahin antara lain :

(a) Harus membayar uang pemeliharaan dan keamanan;

(b). Membayar biaya administrasi;

(c). Membayar asuransi;

(d). Membayar denda bila telat dalam pelunasan hutang;

(e). Menjual barang yang di gadaikan bila tidak mampu melunasi hutangnya.

Sedangkan penerima gadai juga ada perjanjian yang kedua belah sepakati antara lain:

(a) Wajib memelihara barang dan mengamankan dari segala kerusakan;

(b) Akan mengganti barang apabila karena kelalaian petugas gadai untuk mengamankan dan memelihara barang gadai;

(c) Menyerahkan barang gadai bila rahin telah melunasi pinjamannya.

Berdasarkan penjelasan dalam fiqih muamalah, akad yang dibuat oleh para pihak di Pegadaian Syariah telah memenuhi rukun yang tercantum dalam akad gadai syariah tersebut.

Landasan dalam operasionalisasi gadai syariah adalah Fatwa Dewan Syariah Nasional Nomor 25/DSN-MUI/III/2002 tanggal 26 Juni 2002 yang menyatakan bahwa pinjaman dengan menggadaikan barang sebagai jaminan utang dalam bentuk rahn diperbolehkan dengan ketentuan sebagai berikut :

a. Ketentuan Umum:

(1) Murtahin (penerima barang) mempunya hak untuk menahan Marhun (barang) sampai semua utang rahin (yang menyerahkan barang) dilunasi. 
(2) Marhun dan manfaatnya tetap menjadi milik Rahin. Pada prinsipnya marhun tidak boleh dimanfaatkan oleh murtahin kecuali seizin Rahin, dengan tidak mengurangi nilai marhun dan pemanfaatannya itu sekedar pengganti biaya pemeliharaan perawatannya.

(3) Pemeliharaan dan penyimpanan marhun pada dasarnya menjadi kewajiban rahin, namun dapat dilakukan juga oleh murtahin, sedangkan biaya dan pemeliharaan penyimpanan tetap menjadi kewajiban rahin.

(4) Besar biaya administrasi dan penyimpanan marhun tidak boleh ditentukan berdasarkan jumlah pinjaman.

(5) Penjualan marhun

(a) Apabila jatuh tempo, murtahin harus memperingatkan rahin untuk segera melunasi utangnya.

(b) Apabila rahin tetap tidak melunasi utangnya, maka marhun dijual paksa/dieksekusi.

(c) Hasil Penjualan Marhun digunakan untuk melunasi hutang, biaya pemeliharaan dan penyimpanan yang belum dibayar serta biaya penjualan.

(d) Kelebihan hasil penjualan menjadi milik rahin dan kekurangannya menjadi kewajiban rahin.

b. Ketentuan Penutup

(1) Jika salah satu pihak tidak dapat menunaikan kewajibannya atau jika terjadi perselisihan diantara kedua belah pihak, maka penyelesaiannya dilakukan melalui Badan Arbitrase Syariah setelah tidak tercapai kesepakatan melalui musyawarah.

(2) Fatwa ini berlaku sejak tanggal ditetapkan dengan ketentuan jika di kemudian hari terdapat kekeliruan akan diubah dan disempurnakan sebagai mana mestinya.

\section{Metode Penelitian}

Menurut Sugiyono (2006:24), metode deskriptif yaitu dengan mengumpulkan, mengolah dan menginterpretasikan data yang diperoleh sehingga dapat memberikan gambaran jelas mengenai keadaan yang ditelliti. 
Berdasarkan sifatnya penelitian ini dikategorikan sebagai penelitian studi lapangan karena penelitian ini hanya mengumpulkan data, mencari fakta, kemudian menjelaskan dan menganalisis data yaitu dengan cara pengumpulan dan penyusunan data, selanjutnya dianalisis dan diinterpretasikan berdasarkan landasan teori yang ada. Dalam metode penelitian ini digunakan perhitungan dari data statistik untuk menguji hipotesis.

Sugiyono (2011:7) menyatakan:

Metode survey adalah penelitian yang dilakukan pada populasi besar maupun kecil tetapi data yang dipelajari adalah data yang diambil dari sampel yang diambil dari populasi tersebut, sehingga ditemukan kejadian-kejadian relatif, distribusi, dan hubungan-hubungan antar variabel sosiologis maupun psikologis.

Dalam metode survey yang dilakukan dalam penelitian ini, digunakan kuesioner sebagai alat pengumpulan data pokok. Sampel yang diambil sebanyak 80 orang.

\subsection{Populasi}

Menurut Sugiyono (2010:61), populasi adalah wilayah generalisasi yang terdiri atas objek/subjek yang mempunyai kualitas dan karakteristik tertentu yang ditetapkan oleh peneliti untuk dipelajari dan kemudian ditarik kesimpulannya.

Sedangkan, Suharsimi Arikunto (2006:130) menyatakan:

"Populasi adalah keseluruhan subjek penelitian. Apabila seseorang ingin meneliti semua elemen yang ada dalam wilayah penelitian, maka penelitiannya merupakan penelitian populasi. Studi atau penelitiannya juga disebut studi populasi atau studi sensus.”

Populasi dalam penelitian ini adalah seluruh nasabah Pegadaian Syariah yang ada di Kabupaten Karawang yang terkait dengan penelitian yang dilakukan pada Perusahaan Pegadaian Syariah Cabang Karawang adalah sebanyak 80 orang.

\subsection{Teknik Pengambilan Sampel}

Penulis menggunakan teknik pengambilan sampel Probability Sampling dengan teknik Random Sampling. Karena jumlah populasi belum diketahui maka pengambilan sample dilakukan secara random sebanyak 80 responden. 


\subsection{Jenis Dan Sumber Data}

Dalam penelitian ini data yang dikumpulkan meliputi data primer dan data sekunder:

1. Data Primer

Merupakan data yang diperoleh secara langsung dengan cara melakukan wawancara langsung dengan pihak-pihak yang berhubungan dengan penelitian yang dilakukan, data primer pada umumnya merupakan data kualitatif dan digunakan untuk membuktikan hipotesis yang telah dikemukakan sebelumnya. Data primer diperoleh dengan mengadakan penelitian dan kuesioner.

2. Data Sekunder

Merupakan data yang berfungsi sebagai pelengkap data primer. Data sekunder dapat diperoleh melalui media lain yang bersumber pada buku-buku perpustakaan, internet, jurnal dan data-data lainnya dari perusahaan.

\subsection{Teknik Pengumpulan Data}

Untuk memperoleh data, penulis menggunakan teknik pengumpulan data sebagai berikut:

1. Observasi

Observasi adalah teknik pengumpulan data dengan cara melakukan pengamatan langsung dilokasi tempat penelitian untuk memperoleh data yang diperlukan. Penulis melakukan penelitian di PT. Pegadaian Syariah Cabang Karawang.

2. Wawancara

Wawancara adalah teknik pengumpulan data dengan cara mengadakan tanya jawab dengan pejabat atau pelaksana yang berwenang yaitu pejabat dibagian Humas maupun pejabat dibagian audit internal atau tim pengawas juga pejabat di bagian lainnya untuk mengetahui informasi lebih terkait data penelitian dari perusahaan.

3. Kuesioner 
Kuesioner adalah teknik pengumpulan data melalui pertanyaanpertanyaan yang berbentuk lembar isian yang disiapkan oleh penulis dengan mempertimbangkan masalah yang sedang diteliti dan akan dijawab oleh pihak-pihak yang berhubungan dengan permasalahan yang akan diteliti.

\section{Tabel 3. 1 Kriteria Jawaban dan Skoring Penilaian Responden}

\begin{tabular}{|c|c|}
\hline Kriteria Jawaban & Skor \\
\hline Sangat Setuju (SS) & 5 \\
\hline Setuju (S) & 4 \\
\hline Cukup Setuju (CS) & 3 \\
\hline Tidak Setuju (TS) & 2 \\
\hline Sangat Tidak Setuju (STS) & 1 \\
\hline
\end{tabular}

\subsection{Transformasi Data Dari Interval Menjadi Ordinal}

Sebelum melakukan pengujian-pengujian statistik, data dari hasil kuesioner yang berskala ordinal ditransformasikan menjadi data interval, hal ini dikarenakan pengujian reliabilitas yang akan dilakukan selanjutnya mengharuskan menggunakan skala pengukuran ordinal.

Pengukuran terhadap variabel independen dan dependen dilakukan dengan menggunakan skala likert yang merupakan skala ordinal. Untuk melakukan analisis data, digunakan Method of Successive Intervals (MSI) untuk mentransformasikan skala ordinal menjadi skala interval.

Tentukan Nilai Skala (NS) dengan menggunakan rumus:

Nilai Skala $=\frac{(\text { Density at lower limit }- \text { Density at upper limit })}{(\text { Area Below Upper limit }- \text { Area below Lower limit })}$ Keterangan:

Density of lower limit $=$ Kepadatan batas bawah

Density of upper limit $=$ Kepadatan batas atas

Area below upper limit $=$ Daerah dibawah batas bawah

Area below lower limit $=$ Daerah dibawah batas bawah 
Tentukan Nilai Transformasi dengan menggunakan rumus:

$$
\text { Score }=\text { Score Value }-\{\text { Scale Value minimum }\}+1
$$

\subsection{Teknik Analisis Data}

Dalam penelitian ini penulis menggunakan program komputer SPSS (Statistic Product and Service Solution) versi 16,0 dan Microsoft Excel 2007. Metode analisis yang digunakan dalam penelitian ini adalah dengan metode deskriptif, dimana data yang diperoleh dianalisis sehingga diperoleh berbagai gambaran yang menunjukkan persepsi masyarakat tentang gadai emas di Pegadaian Syariah. Disamping itu dilakukan pula dengan bentuk analisis lain seperti : grafik tabulasi silang (cross tab), tabel, frekuensi dan gambar (grafik).

\section{Hasil dan Pembahasan}

Nasabah yang dijadikan objek penelitian adalah nasabah yang aktif dan melakukan transaksi pembiayaan Gadai Emas syariah selama 1 tahun terakhir.Berikut terlampir data nasabah yang aktif berdasarkan jenis kelamin. nasabah berjenis kelamin laki-laki yang melakukan pembiayaan gadai emas syariah ada sebanyak 35 orang atau sebesar 43,75\% sedangkan nasabah berje nis kelamin perempuan ada sebanyak 45 orang atau sebesar 56,26\%. Dengan demikian nasabah yang berjenis kelami perempuan lebih banyak dibandingkan nasabah laki-laki.

Berdasarkan data responden berdasarkan usia diketahui bahwa nasabah yang berusia $>41$ tahun ke atas lebih kecil yaitu 21 orang dengan persentase sebesar 26,25\% dibandingkan dengan nasabah yang berumur 20-30 tahun sebanyak 24 orang dengan tingkat persentase 30\% dan 31-40 tahun sebanyak 35 orang dengan tingkat persentase $43,75 \%$. Sedangkan yang berumur $<20$ tahun tidak ada sama sekali yaitu 0 .

Berdasarkan data responden berdasarkan pemahaman dan usia adalah bahwa mayoritas nasabah yang berusia 31-40 tahun lebih memahami tentang proses gadai emas, sebanyak 24 orang dengan persentase $30 \%$ dari total responden menurut pemahaman terhadap proses gadai emas. Untuk yang tidak memahami mayoritas nasabah yang berumur 21-30 tahun, yakni sebanyak 8 orang dengan persentase $10 \%$ dari jumlah responden.

Berdasarkan data antara jumlah tanggungan dan motif dapat dilihat bahwa jumlah responden yang jumlah tanggungannya .4 orang paling banyak yaitu 
sebanyak 38 orang dengan presentase $47,5 \%$ dari jumlah responden. Sedangkan nasabah yang memiliki tanggungan 2-3 orang lebih banyak dibandingkan dengan jumlah tanggungan 0-1 orang dengan motif menggadaikan emas utnuk kebutuhan hidup/konsumsi. Total jumlah responden yang tanggungannya 2-3 orang yaitu 26 orang

Berdasarkan data responden berdasarkan pekerjaan dapat diketahui bahwa didominasi oleh nasabah yang pekerjaannya PNS yaitu sebanyak 40 orang dengan persentase $50 \%$ dari total jumlah responden. Kemudian pekerjaan wiraswasta sebanyak 29 orang dengan presentase $36,25 \%$ dari total jumlah responden. Selanjutnya adalah pekerjaan lain-lain seperti tukang becak, tukang bakso, pembantu rumah tangga, buruh pabrik, dll sebanyak 21 orang dengan persentase $26,25 \%$ dari total jumlah responden.

Berdasarkan data responden apakah mempunyai pekerjaan tambahan atau tidak dapat diketahui bahwa didominasi nasabah yang tidak mempunyai pekerjaan tambahan yaitu sebanyak 48 orang dengan persentase $60 \%$ dari total jumlah responden. Kemudian yang kadang-kadang ada pekerjaan tambahan sebanyak 22 orang dengan persentase $27,5 \%$ dari total jumlah responden. Selanjutnya adalah yang ada mempunyai pekerjaan tambahan sebanyak 10 orang dengan persentase $12,5 \%$ dari total jumlah responden.

Tabel 4.1

Penyajian Data dan Analisis Deskriptif Data Alasan Nasabah Menggadaikan Emasnya di Pegadaian Syariah

\begin{tabular}{|c|c|c|}
\hline $\begin{array}{c}\text { Alasan nasabah } \\
\text { menggadiakn emasnya di } \\
\text { Pegadaian Syariah }\end{array}$ & Frekuensi & Persentase \\
\hline Kebutuhan hidup/konsumsi & 51 & 63,75 \\
\hline Modal usaha & 22 & 27,5 \\
\hline Sekolah & 7 & 8,75 \\
\hline Total & $\mathbf{8 0}$ & $\mathbf{1 0 0}$ \\
\hline
\end{tabular}

Sumber : Data Primer 
Menjadi alasan utama nasabah memilih menggadaiakn emasnya di Pegadaian Syariah adalah karena untuk kebutuhan hidup/konsumsi. Hal ini dapat dilihat dari jumlah responden yang memilih alasan kebutuhan hidup sebanyak 51 orang dengan persentase $63,75 \%$. Kemudian diikuti dengan alasan modal usaha sebanyak 22 orang dengan persentase $27,5 \%$. Sedangkan pada posisi terkahir responden yang memilih alasan untuk sekolah ada sebanyak 7 orang dengan preentase $8,75 \%$. Dapat disimpulkan bahwa yang menjadi alasan terbesar nasabah dalam menggadaikan emasnya di Pegadaian Syariah adalah untuk kebutuhan hidup/konsumsi yang mereka butuhkan.

Sedangkan dari data terlihat jelas bahwa variabel lokasi sangat mempengaruhi masyarakat bertransaksi atau menggadaikan barang atau emasnya di Pegadaian Syariah. Kedekatan lokasi Pegadaian Syariah dengan tempat kegiatan responden dan kemudahan pencapaian Pegadaian Syariah, terlihat dari jawaban 39 responden menyatakan setuju dengan kedekatan lokasi Pegadaian Syariah dan 30 responden menyatakan sangat setuju namun hanya 2 responden yang menyatakan tidak setuju dari total responden. Kemudahan pencapaian Pegadaian Syariah dipicu juga dengan sarana dan prasarana untuk mencapai tempat dimana Pegadaian Syariah beroperasi misalnya saja seperti transportasi. Namun dapat kita lihat menyatakan setuju dengan kemudahan pencapaian Pegadaian Syariah tersebut dengan jumlah responden 35 orang, 40 responden yang menyatakan sangat setuju dan 5 orang dari total responden yang menyatakan kurang setuju.

Dari alasan nasabah memilih Pegadaian Syariah sebagai suatu solusi dalam menggadaikan emas dapat dilihat bahwa alasan nasabah memilih Perum Pegadaian Syariah sebagai solusi dalam menggadaiakan emas mempunyai alasan yang beragam. Hal itu didasarkan pada jumlah responden sebanyak 47 orang atau sebesar $58,75 \%$ dari total responden menyatakan bahwa alasannya menggadaikan emas di Pegadaian Syariah karena proses menggadaikan emas dengan syarat yang mudah, cepat dan aman. Sebanyak 29 orang atau sebesar 36,25\% dari total responden menyatakan segala biaya yang ada persentasenya 5\% kecil, sehingga tidak memberatkan peminjam. Sebanyak 3 orang atau sebesar 3,75\% dari total responden menyatakan tidak ada pilihan lain.Dengan demikian dapat disimpulkan bahwa nasabah menggadaikan emasnya di Pegadaian Syariah dengan alasan karena proses 
menggadaikan emas dengan syarat yang mudah, cepat dan aman.

\section{Kesimpulan dan Saran}

\subsection{Simpulan}

1. Dari alasan nasabah memilih Pegadaian Syariah sebagai suatu solusi dalam menggadaikan emas dapat dilihat bahwa alasan nasabah memilih Perum Pegadaian Syariah sebagai solusi dalam menggadaiakan emas mempunyai alasan yang beragam. Hal itu didasarkan pada jumlah responden sebanyak 47 orang atau sebesar $58,75 \%$ dari total responden menyatakan bahwa alasannya menggadaikan emas di Pegadaian Syariah karena proses menggadaikan emas dengan syarat yang mudah, cepat dan aman. Sebanyak 29 orang atau sebesar $36,25 \%$ dari total responden menyatakan segala biaya yang ada persentasenya 5\% kecil, sehingga tidak memberatkan peminjam. Sebanyak 3 orang atau sebesar 3,75\% dari total responden menyatakan tidak ada pilihan lain.Dengan demikian dapat disimpulkan bahwa nasabah menggadaikan emasnya di Pegadaian Syariah dengan alasan karena proses menggadaikan emas dengan syarat yang mudah, cepat dan aman.

2. Motif utama nasabah memilih menggadaiakn emasnya di Pegadaian Syariah adalah karena untuk kebutuhan hidup/konsumsi. Hal ini dapat dilihat dari jumlah responden yang memilih alasan kebutuhan hidup sebanyak 51 orang dengan persentase $63,75 \%$. Kemudian diikuti dengan alasan modal usaha sebanyak 22 orang dengan persentase $27,5 \%$. Sedangkan pada posisi terkahir responden yang memilih alasan untuk sekolah ada sebanyak 7 orang dengan preentase $8,75 \%$. Dapat disimpulkan bahwa yang menjadi alasan terbesar nasabah dalam menggadaikan emasnya di Pegadaian Syariah adalah untuk kebutuhan hidup/konsumsi yang mereka butuhkan.

\subsection{Saran}

Mengacu kepada kesimpulan di atas, peneliti juga mengajukan saran-saran atau rekomendasisebagai berikut:

1. Bagi perusahaan sebaiknya lebih banyak melakukan sosialisasi-sosialisasi mengenai produk-produk yang dimiliki pegadaian syariah. Karena jika dilihat masih banyak masyarakat yang belum banyak mengetahui tentang pegadaian syariah dan produk yang dimilikinya.; 
2. Mengenai lokasi unit yang hanya berada pada pusat kota saja, contohnya di Kabupaten Karawang unit pegadaian syariah hanya berada pada pusat kota saja yaitu unit By-pass, Uunit Johar dan Unit Galuh mas. Sedangkan jika dilihat dari geografisnya ketiga unit tersebut belum mamp untuk memenuhi kebutuhan masyarakat Kabupaten Karawang. Artinya sebagai saran untuk pegadaian syariah sebaiknya juga penempatan unit-unit pegadaian syaraiah di setiap Kecamatan. Setiap Kecamatan memiliki 1 unit jumlah nasabah untuk tahun-tahun berikutnya, karena lebih dekat dengan masyarakat;

3. Untuk masyarakat muslim sebaiknya lebih memilih pembiayaan yang berbasis syariah. Karena akan lebih banyak mashlahatnya dibandingkan mudharatnya.

\section{Daftar Pustaka}

Ali, Zainuddin. 2008. Hukum Gadai Syariah. Jakarta : Sinar Grafika

Antonio, Muhammad Syaafi'i. 2011. Bank Syariah dari Teori ke Praktik. Jakarta :Gema Insani.

H. Sulaiman Rasjid. Fiqh Islam. Bandung: Sinar Baru Algensindo. 1994.

Habiburrahman dan Rahmawati, Yulia. 2012. Mengenal Pegadaian Syariah. Jakarta : Kuwais.

Jalaluddin Rahmat, 2003. Psikologi Komunikasi. Remaja Rosdakarya : Bandung.

Kasmir. Bank dan LembagaKeuangan Lainnya. (Jakarta : rajawali Press, 2008)

Muhammad. Metode Penelitian Ekonomi Islam: Pendekatan Kuantitatif. Jakarta: Rajawali Pers. 2008.

Nurul Huda dan Mohammad Heykal, LembagaKeuangan Islam: Tinjauan Teoritis dan Praktis (Jakarta: Kencana, 2010)

Otoritas Jasa Keuangan. Laporan Triwulan. Dalam http://www.ojk.go.id. Diakses pada tanggal 17 November 2014 pkl. 09.25

Peraturan Menteri Keuangan No. 84/PMK.012/2006 tanggal 29 September 2006.

Rais, Sasli.. PEGADAIAN Operasional (Suatu Kajian Kontemporer). Jakarta : Universitas Indonesia (UI-Press SYARIAH: Konsep dan Sistem). 2006.

Rahmat Syafi'I. Fiqh Muamalah. Bandung: CV Pustaka Setia. 2004.

http://www.pegadiaian.co.id. diakses 06 Februari 2017 pkl. 10.25 